\title{
Giving peace a chance: Organizational leadership, empowerment, and peace ${ }^{\dagger}$
}

\author{
GRETCHEN SPREITZER* \\ Stephen M. Ross School of Business, University of Michigan, Ann Arbor, Michigan, U.S.A.
}

\begin{abstract}
Summary
This paper provides an exploratory look at how the leadership practices of business organizations may foster more peaceful societies. I develop the logic for positive relationships between participative organizational leadership, employee empowerment, and peace. I offer several mechanisms to explain why these different manifestations of voice are likely to contribute to peaceful societies. I then draw on several cross-national databases to provide a preliminary examination of the hypotheses. I find support for the hypotheses regarding the positive effects of participative leadership and employee empowerment in work organizations on peace. The paper concludes by discussing contributions of this research to the organizational studies literature and offers directions for future research. Copyright (C) 2007 John Wiley \& Sons, Ltd.
\end{abstract}

All we are saying is give peace a chance.

- John Lennon

\section{Introduction}

Academic research on peace is normally in the domain of politicians, policy makers, political scientists, or historians. Peace is not normally part of our lexicon as organizational scientists. This topic is outside the realm of much of organizational scholarship which tends to focus on individual, group, organizational or industry level outcomes. But should that be the case, given that business organizations can and do have far reaching effects on local and global communities (Friedman, 2000; Walsh, 2005)? Can business organizations contribute positively to peace? ${ }^{1}$ Peace may be defined as the reduction of

* Correspondence to: Gretchen Spreitzer, Stephen M. Ross School of Business, University of Michigan, Ann Arbor, MI 48109-1234, U.S.A. E-mail: spreitze@umich.edu

${ }^{\dagger}$ An earlier version of this paper was presented at an All Academy Symposium entitled 'A role for organizations in sustainable peace' at the 2005 National Academy of Management Meetings, August 7-10, Hawaii.

${ }^{1}$ The inspiration for these ideas comes from the 2002 academic conference envisioned by Tim Fort and Cindy Schipani, with the support of the Aspen Institute, at the Ross School of Business at the University of Michigan. They invited me to think about how my research on empowerment might offer insights on how the leadership of business organizations can contribute to peace. Without their stimulus, I doubt I would have initiated research in this domain - in fact, most of my research has focused on the individual or group level of analysis. It is certainly a stretch experience for me, and likely for most organizational scholars, to think about studying organizational effects on major societal outcomes such as peace. 
violence, unrest, and war (Fort \& Schipani, 2002). If business organizations can make even a small contribution to creating more peace in the world, it is a question worth investigating, for Franklin Roosevelt tells us that 'peace begins at home'.

Over the last few years, there has been increased interest in understanding how business organizations may contribute to international peace:

- In 2000, United Nations Secretary-General Kofi Annan challenged business organizations to join the Global Compact — an international initiative that would bring companies together with UN agencies to advance 10 universal principles in the areas of human rights, labor, the environment, and anticorruption (Global Compact, 2006).

- From 2001 to 2003, Tim Fort and Cindy Schipani organized a series of conferences in conjunction with the William Davidson Institute at the University of Michigan and the Aspen Institute on how business can contribute to pace. These were ground breaking in getting business school academics to consider this question in their own research. Follow-up conferences are happening at George Washington University's Institute for Corporate Responsibility Program on Peace through Commerce.

- The Weatherhead School of Business at Case Western Reserve University created the Center for Business as an Agent of World (BAWB) Benefit to explore the many ways business can contribute to achieving peace and prosperity as proclaimed by the UN Global Compact (Cooperrider, 2006).

- The Prince of Wales International Business Leaders Forum was created to promote responsible business practices that benefit business and society throughout the world. Today the 70-plus member companies have initiatives in over 50 countries in order to achieve the Global Compact goals, promote peace, reduce global poverty, and promote economic stability (Prince of Wales International Business Leaders Forum, 2006).

- Even the Association to Advance Collegiate Schools of Business (AACSB) is getting on board with their sponsorship of an initative on 'Peace Through Commerce: Partnerships As The New Paradigm'

(AACSB, 2006). The basic premise is that business can be much more than a pathway to prosperity - it can be a catalyst for world peace.

Clearly, the issue of how business may contribute to peace is garnering significant attention. Yet, to date, we have almost no empirical research that explores how business may contribute to peace in the world. This paper is a first step in that direction. In this paper, I explore two ways that business organizations may generate seeds for sowing peace. This paper goes beyond the usual terrain of organization studies to stimulate our thinking about the possible role that the leadership of business organizations can play in fostering peace. Of course, peace is complex and impossible for any one organization to foster alone. But through their collective leadership, business organizations potentially can play a role in fostering peace (Fort \& Schipani, 2004: 24). In the section below, I offer some initial theoretical background on the role of business organizations in fostering peace. I suggest some preliminary hypotheses about how the leadership practices of business organizations may create the conditions for more peace. I then describe the research methods, analyses, and results. The paper ends with a discussion regarding next steps in peace research.

\section{Theoretical Background}

Recent dialogue on the topic of corporate social responsibility provides some insights into the broader impact of business organization on society. Ever since Milton Friedman (Friedman, 1970) declared that 
the 'social responsibility of business is to increase profits', supporters and opponents of corporate social responsibility have debated the moral obligations of the firm. The advent of stakeholder theory (Freeman, 1984) helped legitimate the possibility that corporations have moral responsibilities beyond increasing shareholder value. Stakeholder theory moves managerial action toward a more external focus beyond stockholders to key strategic stakeholders - that is, anyone who can affect or is affected by the achievement or the activities of an organization (Friedman, 1970; Post, Preston, \& Sachs, 2002; Walsh, 2005). Following this line of reason, then, a peaceful society can be considered a key stakeholder for business organizations (Fort, 2007). In fact, it is often taken-for-granted that a peaceful society is a precondition for most business organizations to thrive (the exception would be defense contractors and suppliers who are in the business of war).

Today's charges that corporations exploit international labor markets, contribute to environmental catastrophe, and take advantage of local communities are not new (Barber, 1995; Brief, Buttram, \& Dukerich, 2000; Walsh, Weber, \& Margolis, 2003). Critics of business have been quick to point out that multinational corporations ought to be better world citizens (e.g., Korten, 1996). Companies such as General Electric, General Motors, and Merck have responded with extensive community development programs. Others, such as Nike and Target, have developed supplier codes of conduct to reduce child labor, sweatshop conditions, and environmental damage. Yet, while these programs can encourage and help business organizations become better global citizens, I suggest that there are other more subtle forces by business may make a more profound contribution to peace societies (Fort \& Schipani, 2004).

\section{How Business Organizations Can Contribute to Peace: Mapping What We Know}

In the literature, business organizations are theorized to contribute to peace in several ways (Fort \& Schipani, 2004). First, business organizations can increase trade. Increasing trade may contribute to peace because prior research has shown that trading partners are unlikely to go to war with each other (Nichols, 1999). The idea is that countries will be more likely to work through conflicts when foreign trade is at stake (Friedman, 2005). For example, when a U.S. spy plane made an emergency landing in China in 2001 after colliding with a Chinese fighter jet sent to intercept it, the two nations worked very hard to keep the situation from escalating given their important and growing trade ties.

Second, business organizations can engage in 'track two' diplomacy which can reduce the likelihood of war (Fort \& Noone, 2000). Track two diplomacy, also known as citizen diplomacy, involves nongovernmental, informal, and unofficial forms of conflict resolution between citizen groups (like companies). It is aimed at de-escalating conflict by reducing anger, fear, and tension and by improving communication and mutual understanding.

And third, Nobel Prize winning economist Amartya Sen (1999) suggests that business organizations can enhance the economic well-being of citizens around the world. This enhanced economic well- being can combat the marginalization of the poor (Prahalad, 2004; Sachs, 2005) and reduce the threat of violent reaction borne of desperation (Fort \& Schipani, 2004; Sen, 1999). For example, Gandhi (Nanda, 1996) made a strong case that poverty was one of the greatest contributors to societal violence - whether it be crime or civil unrest. When people do not have enough food to eat, clean water to drink or safe housing, they will do whatever is necessary to survive including rising up against authority. 
My purpose in this paper is to go beyond the conventional wisdom-beyond these three traditional ways that business organizations are believed to contribute to peace - and offer a fourth. This paper suggests that business organizations can contribute to peace through their leadership approach (Beck-Dudley \& Hanks, 2003; Fort \& Schipani, 2004; Milliken, 2002). More specifically, I suggest that participative organizational leadership and employee empowerment can create conditions within organizations that approximate the attributes of peaceful societies. These models of peaceful organizing can then be emulated by citizens in civic and political domains. In the next section of the paper, I offer some initial hypotheses regarding how the organizational leadership and empowerment practices within business organizations can contribute to creating peaceful communities.

\section{Why Participatory Systems Might Matter}

In a study of the social preconditions of peace, anthropologist David Fabbro (1978) identified a number of common characteristics of peaceful societies. In addition to several criteria regarding environmental habitat (e.g., rain forest vs. desert) and type of subsistence (e.g., hunter-gatherers versus agricultural), Fabbro found that peaceful societies had: (1) open and egalitarian decision-making and (2) social control processes which limit the use of coercive power. These two things are the hallmarks of participatory systems that empower people in the collective.

Why should participatory systems that involve and empower citizens matter for peace? Participatory systems allow citizens to use their voices to influence policy, protect human rights, and hold their governments accountable. When citizens participate, they see the system as more procedurally fair, which reduces the likelihood of grievances growing into flashpoints of unrest or violence. Participation also provides checks and balances so that single points of ideology do not prevail. In contrast, totalitarian systems, where one person or political group completely dominates others through the use of coercive power, polarize people which can in turn lead to conflict or even violence. Totalitarian systems enable a command and control focus over the collective that may create short-term peace through autocracy but not long-term peace. Thus, participatory systems may contribute to peace because they foster open and egalitarian decision-making and provide social controls that reduce the potential for coercive power (Fort \& Schipani, 2004; Peck, 1988; Weart, 1998).

Most often in peace research, the participatory systems that are studied are democratic governments where people have a voice in the workings of the political system (Bobbitt, 2002). Fort and Schipani (2004) provide a sophisticated commentary on why democratic nation states provide a favorable environment for peace. Peck (1988) argues that participatory systems can be manifest in systems beyond the formal government. This paper suggests that business organizations can introduce participatory systems that can be a model for peaceful societies and can thus contribute to peace beyond the workplace context.

How might this happen? A business organization can empower employees to have voice and make decisions relevant to their work. Many contemporary business practices such as total quality management advocate having employees have a say in problem-solving to point out defects in quality or service. As a result of this empowerment, the affected employees understand more open and egalitarian ways of interacting with peers, bosses, and other stakeholders like customers and suppliers. They can see the real benefits of these participatory practices to themselves and their company. Their subsequent attraction to these egalitarian and open work practices could then spill over to civic life and subsequently nourish democratic tendencies toward citizen involvement in political arenas. As citizens request more opportunities for open and egalitarian decision-making in civic and political matters, there may be a tangible effect on peace in the societies they live in-beyond the peaceful outcomes 
they may experience in their work life. Three real-world examples demonstrate how this process may occur.

\section{Unilever in Vinhedo Brazil}

Consider the case of Unilever opening a plant to produce personal products in Vinhedo, Brazil. In general, about half of Vinhedo's citizens fail to finish grammar school, and 20 per cent are illiterate. In addition to remedial and technical skills, Vinhedo employees at Unilever are trained in empowerment and total quality management. Their exposure to these participatory practices has had powerful effects; 'Now, people don't have to wait for the nod from management ... they do it themselves ... they make their own adjustments, do their own ordering, and have begun to handle their own budgets' (Unilever, 2005). One employee described how the program 'changed my life... a true exercise in citizenship ... offering sight to people who cannot see'. Employees learn that 'everyone can make a contribution and everyone can make a difference' whether at work or in their community (Unilever, 2005).

The empowerment of Unilever workers in Vinhedo not only benefits the workers and the company but also the wider community. The employees understand they have a voice which contributes to a growing sense of collective agency. Through this experience, Unilever employees in Vinhedo develop a taste and even an expectation for having a 'say'. Employees also develop individual skills pertinent to having effective voice in social systems. Given the positive nature of this experience, they are likely to develop expectations for and seek out opportunities for voice and empowerment in civic matters which in turn may create more conditions for a peaceful society. For example, employees sought to extend the training programs beyond the company, first to the families of employees, and now in partnership with the local government and local colleges for the wider community. Improving the literacy and agency of the community in turn may lead to a more peaceful Brazilian society because its citizens have the skills necessary for democratic participation.

\section{Rainforest Expeditions in Peru}

In addition, consider the case of Rainforest Expeditions (RFE), an ecotourism company based in Peru. In 1998, they opened a lodge in partnership with the indigenous Infierno people (Reuters, 2001). To run the lodge, RFE employs people of the community in many jobs; initially, they work as cooks and housekeepers, but with intensive training including English lessons, they are also later employed as guides and lodge managers. The community gets two thirds of the lodge's profits, and by 2016, the community will take over full control from RFE. RFE has created a successful community and private partnership, working to develop a profitable ecotourism product that effectively catalyzes the conservation of natural and wildlife resources. ${ }^{2}$

As a result of their partnership with RFE, the Infierno people have developed a sense of collective agency by reaffirming their culture and preserving their identity as a community. The profits have enabled them to build a secondary school — the only one in the area- and fund a medical post. Their sense of collective agency has spilled over to civic matters as well. The Infierno community has formed committees to work on strategic plans for sectors such as agriculture, education, ecotourism, and handicrafts. The ecotourism committee is offering management training, while the handicraft committee has built a workshop and organized training to enable more of the community to make a

\footnotetext{
${ }^{2}$ This stands in contrast to other parts of the world where indigenous people are chopping down the rainforest in a futile effort to create farmland so they can have a livelihood. But within a short time, the land is depleted and eroded and the environment has been irrevocably damaged.
} 
living from tourism. The Infierno people have also developed a greater sense of voice in political matters as they negotiate with the President of Peru to set up an agrarian bank, which is seen as a vital means for them to find credit for their small-scale farming ventures. This growing sense of collective agency may also help combat the historical influence of the 'Shining Path' terrorist group that has held influence over many parts of the Peruvian nation. This partnership has enabled more participation of the Infierno people, reduced poverty and unrest, and enabled the development of a more peaceful society.

\section{Futureways in Northern Ireland}

Finally, consider the case of Futureways, a company in Northern Ireland that purposefully hires equal numbers of Catholics and Protestants (Nelson, 2000). In ordinary life in Northern Ireland, Catholics and Protestants are largely segregated into separate schools, neighborhoods, and leisure activities. They see each other more as enemies than as neighbors. The opposing groups rarely, if ever, have a chance to know each other as people. This tension has contributed to unrest in Northern Ireland for a very long time. The workplace therefore, is a place of great potential for transforming unrest. Futureways has Catholics and Protestants working side by side, empowering them to work together in teams. Futureways employees have a greater sense of collective efficacy regarding their ability to cooperate with people who are different than themselves. This cooperative mindset and behavior is also likely to affect their willingness to interact with those of a different denomination in their private and civic lives. In short, Futureways provides a concrete way for conflicting groups of people to work together toward a common good. With Futureways' help, these citizens of Northern Ireland are creating pockets of peace in a warring country.

\section{Hypotheses Development}

These three real-world examples offer some insights on how business organizations can serve as 'mediating institutions' (Fort \& Schipani, 2004: 102) that can create participatory systems to empower and involve people in ways that create more 'peaceableness' or preferences for peace (Beck-Dudley \& Hanks, 2003). Because corporations are relatively smaller than nation states, allow face-to-face interactions, and can enable voice, they can more easily create authentic community and become a model for peaceful societies. Through mediating institutions, human values of the collected are developed because there is 'a direct, recognizable consequence to actions ... individuals obtain a sense meaning of who they are as human beings in part as members of an organization that interfaces with the rest of the word, but also in part, in terms of the values that must be internalized and regularly practices in order to be a good citizen' (Fort, 2007).

To better understand how business organizations can serve as mediating institutions for peace, this paper focuses on two ways that organizations can enable participative systems that are open and egalitarian: (1) through a participative organizational leadership and (2) through employee empowerment practices. The logic for specific hypotheses on each are articulated below.

\section{A short note on levels}

The logic is somewhat complicated because it crosses levels. Both organizational leadership and empowerment are features of the organization. Yet, we are interested in linking these organizational features to peace which is a characteristic of a society or a country. Obviously, there are many business organizations that reside within a country. As such, research by the Global Leadership and Organizational Behavior Effectiveness (GLOBE) Research Project housed at the Wharton Business School (House, Javidan, Hanges, \& Dorfman, 2002) makes the case that societies or countries have 
tendencies toward certain kinds of leadership of business organizations. They suggest that you can aggregate leadership styles across business organizations within a country, and then link those collective features to outcomes, like peace, that operate at a country level. So in developing this logic, I suggest several ways in which these two organizational features can create more peaceable conditions in companies and communities that can, in turn, foster peace in civic and governmental domains.

The logic is complicated because we also know that workplace development and socialization can have sustained effects on worker proactiveness (e.g. Frese \& Day, 2001; Parker, 2000). Leadership styles impact worker opportunities to develop capabilities and beliefs about the future, which can also spill over into the larger society. But of course multiple feedback loops exist. Peace in a country may increase opportunities for worker proactiveness and empowerment because there is more stability and likely more prosperity. Nonetheless central to the experience of people in a society is their day-to-day encounter with authority, including business leaders in the firms where they work and interact as customers.

\section{Effect of a participative organizational leadership style on peace}

Leadership is defined as the ability of an individual to influence, motivate, and enable others to do what they would not do otherwise (House et al., 2002: 4). Leaders matter because they create and sustain organization strategy, cultures, and practices. Here the focus is on the leadership of business organizations, not the leadership of governments, which is often the focus of peace research. Participative leadership is defined as leadership that involves employees across levels of the hierarchy in decision-making. It is a hallmark of what is often termed as organizational democracy (Harrison \& Freeman, 2004). Participative leaders involve their subordinates in making and implementing decisions (House, Hanges, Javidan, Dorfman, \& Gupta, 2004). They seek subordinates' input on important decisions and value others' points of view. Participative leaders also tend to be more tolerant of differences because they know that those differences can improve decision-making. This paper describes several mechanisms by which participative organizational leadership may enable peace. Mechanisms are the explanations or 'cogs and wheels' (Anderson et al., 2005) of participative organizational leadership that may matter for peace.

The first mechanism by which participatory organizational leadership may matter for peace is through legitimacy of this leadership style. This paper suggests that organizational leaders who successfully use a participative approach can legitimize this style of leadership in the eyes of employees. When employees see and become familiar with the value of a more participatory leadership style, they may see this kind of leadership as equally appropriate for civic and governmental leaders and seek it out. For example, employees who have had a participative leader at work may be more supportive of governmental leaders who have a more participative style. And, prior research indicates that countries ruled by more participatory leaders are more prone to peace (Nichols, 1999; Peck, 1988).

The second mechanism by which participatory organizational leadership may matter for peace is through increased attraction to opportunities for voice. When employees have had a positive experience with participative leadership in their work context, they are likely to be attracted to participative leadership in other contexts as well. They are likely to desire and seek out a similar approach in civic and political life. And when employees can participate and have a say in governance issues, they are likely to feel respected and appreciated, and thus be further attracted to participative leadership in other settings, whether at work or in civic or governmental domains. And again, prior research indicates that participative systems create conditions for peace because people are more likely to resolve disputes with words, and not with more violent means (Nichols, 1999; Peck, 1988). 
H1: More participative organizational leadership in a country will be related to higher levels of peace in that country.

\section{Effect of employee empowerment on peace}

Empowerment can be defined as having voice at work (Spreitzer, 1995). Like participative leadership, empowerment is also a hallmark of what might be labeled as organizational democracy (Harrison \& Freeman, 2004) or dialogic democracy (Powley, Fry, Barrett, \& Bright, 2004). When individuals have opportunities for voice at work, they feel they can make a difference in their work environment. Empowerment may be manifest in flat structures where managers have wide spans of control that avoid a lot of centralized decision-making and layers (Spreitzer, 1996). Empowering organizations provide opportunities to voice concerns. They enable employees to have control over their work product and work environment through job autonomy or self-managing work teams (Spreitzer, 1995). And, empowering organizations develop reward systems like profit sharing or employee ownership that help employees feel as though they have a stake in the success of the organization (Lawler, 1996). In this section, I suggest some logic for how employee empowerment in business organizations can contribute to peace. Again, I offer several mechanisms.

The first mechanism through which empowerment may enhance peace is reducing feelings of helplessness or loss of control. When disempowered, employees are more likely to resort to violence as a way of capturing some influence over their environment. Prior research has demonstrated a significant relationship between feelings of powerlessness and negative deviance including sabotage (Bennett, 1998) and other types of destructive behavior within organizations (Allen \& Greenberger, 1980; Spreitzer \& Mishra, 2000). When individuals feel helpless, they are likely to undertake efforts to restore an essence of control by acting out upon the environment with violence.

When individuals feel disempowered, grievances are more likely to grow into major flashpoints of violence. For example, a study of industrial sabotage by Taylor and Walton (1971) found that workers damaged their plant in order to increase their sense of voice by showing company officials who was in charge. Most recently, Bennett and Robinson (2000) have suggested that the practice of micromanagement (i.e., the opposite of empowerment) is likely to increase organizational and interpersonal deviance as humiliated professionals attempt to regain a perception of control. Through empowerment, business organizations can enable a greater sense of control at work and those feelings of control may carry over into civic and political domains. With a great sense of control at work, employees are less likely to lash out to re-establish a sense of control. For example, as the Solidarity labor movement in Poland helped workers organize free non-communist trade unions. Their participation in the unions gave workers a greater sense of control which over time spilled over into civic and political domains. As they gained more control as a labor movement, they sought more freedom in civic and political domains which eventually led to Poland's move to democracy.

A second mechanism through which empowerment may enhance peace is through building capability for voice. 'Most people spend large part of their daily lives in workplaces, usually in authoritative organizations where they can exercise little influence over their work. The autocratic and hierarchical organizations give people little opportunity to develop democratic skills' (De Jong \& van Witteloostuijn, 2004: 55). Through empowerment practices, business organizations can teach employees the ways of democracy within the borders of the company ${ }^{3}$ (Fort \& Schipani, 2004). It stimulates the development of their competencies and skills to develop their full potential as human beings (De Jong \& van Witteloostuijn, 2004). Having voice in the workplace may provide citizens with

\footnotetext{
${ }^{3}$ Of course, in general, business organizations are not democracies but may contain features of democratic systems (Kerr, 2004).
} 
their first exposure to voice. As employees develop the skills to effectively use their voice in their work environment, they are learning skills like 'issue selling' (Dutton, Ashford, O'Neill, \& Lawrence, 2001), small wins (Weick, 1984), empathy, and compromise (De Jong \& van Witteloostuijn, 2004). Business organizations that give voice to their workers teach them how to participate in open systems of governance that listen to them, without necessarily agreeing with them (Hirschman, 1970). Empowering business organizations give employees skills to institute change or settle conflicts without violence. This can build their self-efficacy for using their voice in civic and governmental domains as well. If business organizations can teach their members these skills, they can use these same skills for civic and political matters to better settle personal disputes without violence. In turn, governments may be more tolerant for hearing competing voices and citizens may be more willing to express their disagreements peacefully, and not violently.

H2: More employee empowerment in business organizations will be related to higher levels of peace in a country.

\section{Research Design}

Collecting cross-country data is complex and time-consuming. A number of scholarly groups have conducted extensive cross-national research on various constructs in our hypotheses. As described below, this paper brings together several different secondary databases to begin exploring our hypotheses. Of course, this means I am limited to the types of measures that others have designed, often to answer a different research question. However, for this early exploratory research, these databases offer an initial examination of my hypotheses.

\section{Measures}

\section{Peace}

A very well-regarded measure of peace is an index produced by the Heidelberg Institute on International Conflict Research (2006) known as the Kosimo Conflict Barometer. It uses a variety of sources and 28 variables to define the types of conflict involved and the methods used by parties to those conflicts to resolve them. It includes incidences of wars, coups d'etat's and peace settlements. However, because it is measured at the incident level rather than the country level, it is hard to use in an empirical analysis. Therefore, this paper includes two proxies to measure peace. The first has been found to be linked to the Kosimo Barometer while the other is a measure of unrest endured by a country.

The first peace proxy focuses on the level of corruption within a country. Corruption is defined as the use of public office for private benefit. I use Transparency International's corruption perceptions index (CPI) to measure this variable because it has been found to be strongly related to the Kosimo peace index (Fort \& Schipani, 2002). Transparency International is a non-governmental organization aimed at fighting corruption, and the CPI reflects individuals' respect for authority inherent in government institutions, rules of laws, and systems of ethics. The surveys used in compiling the CPI focus on bribe-taking by public officials in public procurement. It is a composite index, drawing on 15 different polls and surveys from nine independent institutions carried out among business people and country analysts, including surveys of residents, both local and expatriate. The CPI is a rolling survey of polls taken over the last 3 years, and includes only those 102 countries that are featured in at least three surveys. Countries are scored on a scale from 1 to 10 where 10 indicates the least amount of corruption. I use the most recent index available, which is from 2004. 
The second peace proxy - 'unrest' - is drawn from the Economist Intelligence Unit (EIU) under the heading on politics and institutions. The EIU is the business information arm of the Economist Group that prides itself on its independence in assessing 100 different economies around the world. I created an index of the measures of risk of political instability, armed conflict, social unrest, and international disputes and tensions. Political instability is measured on a scale from 1 to 10 (where 10 indicates higher risk) while armed conflict, social unrest, and international disputes are measured on a scale from 1 to 5 (where 5 indicates a higher risk). I standardized the political stability measure to a 5-point scale and then took the mean of the four measures to create an unrest index. This index of unrest has a reliability of .91. Again, I use the most recent data available in the EIU database, which is from 2004.

\section{Participative leadership}

I take these measures from the GLOBE Research Project (House et al., 2002). The project focused on creating rigorous measures of societal culture and organizational leadership in 61 cultures/countries representing all major regions throughout the world. The questionnaire data consist of responses from approximately 17000 questionnaires from middle managers of approximately 825 business organizations in three industries (financial services, food processing, and telecommunications) in 61 countries. The GLOBE data were collected in the late 1990s.

\section{Employee empowerment}

I measure employee empowerment with items from the World Values Survey (WVS) housed at the University of Michigan, Institute for Social Research (Inglehart \& Baker, 2000). The WVS is conducted via representative national surveys (Inglehart, 1999). Combining its four waves of data collection (1981-82, 1990-91, 1995-98, 1999-2001), the WVS covers 65 societies from all six inhabited continents and over 75 per cent of the world's population, thereby making it the largest worldwide investigation of attitudes, values, and beliefs (Inglehart \& Baker, 2000). I use data from the most recent wave for 40 countries, and we impute data for 15 additional countries from the European Values Survey. (See Table 1 for information on the specific countries we used and from which survey we drew our data.) For the combined 55 countries, the average number of respondents interviewed per country is over 1400 .

Because the latest wave of the WVS contains over 200 questions, in order to determine which questions best represent the essence of employee empowerment, I independently went through the survey with the help of two graduate students to match questions to these two categories. We found two items which allowed us to tap into issues of decision-making freedom and compliance (the opposite of empowerment).

Decision-making freedom is measured with an item asking respondents 'how free are you to make decisions in your job' (C034, EVS 89) $(1=$ none, $10=$ a great deal). Compliance is measured with an item asking respondents 'people have different ideas about following instructions at work. Some say that one should follow one's superior's instructions even when one does not fully agree with them. Others say that one should follow one's superior's instructions only when one is convinced they are right. With which of these two opinions do you agree' (C061, EVS 97) (1=follow instructions, $2=$ must be convinced, $3=$ depends).

\section{Analyses}

Data on the independent variables were collected in the late 1990s through 2001. Data on the dependent variables were collected in 2004. This time sequence is important so that I can see how participative leadership and empowerment are related to corruption and unrest several years later. Of course, 
Table 1. Thirty-two countries for which we have at least one independent variable

\begin{tabular}{|c|c|c|}
\hline Country & GLOBE & $\mathrm{WVS}^{\mathrm{a}, \mathrm{t}}$ \\
\hline Albania & $\mathrm{X}$ & \\
\hline Argentina & $\mathrm{X}$ & $\mathrm{X}$ \\
\hline Australia & $\mathrm{X}$ & $X$ \\
\hline Austria & $\mathrm{X}$ & $\mathrm{X}^{\mathrm{a}}$ \\
\hline Azerbaijan & & $\mathrm{X}^{\mathrm{b}}$ \\
\hline Bangladesh & & $X$ \\
\hline Belgium & & $\mathrm{X}^{\mathrm{a}, \mathrm{b}}$ \\
\hline Bolivia & $\mathrm{X}$ & \\
\hline Brazil & $\mathrm{X}$ & $X$ \\
\hline Bulgaria & & $\mathrm{X}^{\mathrm{b}}$ \\
\hline Canada & $\mathrm{X}$ & $\mathrm{X}^{\mathrm{a}}$ \\
\hline Chile & & $\mathrm{X}$ \\
\hline China & $\mathrm{X}$ & $\mathrm{X}$ \\
\hline Colombia & $\mathrm{X}$ & $\mathrm{X}$ \\
\hline Costa Rica & $X$ & \\
\hline Croatia & & $\mathrm{X}^{\mathrm{b}}$ \\
\hline Czech Republic & & $\mathrm{X}^{\mathrm{a}, \mathrm{b}}$ \\
\hline Denmark & $\mathrm{X}$ & $\mathrm{X}^{\mathrm{a}, \mathrm{b}}$ \\
\hline Dominican Rep & & $\mathrm{X}$ \\
\hline Ecuador & $\mathrm{X}$ & \\
\hline Egypt & $\mathrm{X}$ & \\
\hline El Salvador & $\mathrm{X}$ & \\
\hline Estonia & & $\mathrm{X}^{\mathrm{b}}$ \\
\hline Finland & $\mathrm{X}$ & $\mathrm{X}^{\mathrm{b}}$ \\
\hline France & $\mathrm{X}$ & $\mathrm{X}^{\mathrm{a}, \mathrm{b}}$ \\
\hline Georgia & $\mathrm{X}$ & \\
\hline Germany (west) & $\mathrm{X}$ & $\mathrm{X}^{\mathrm{b}}$ \\
\hline Ghana & & \\
\hline Greece & $\mathrm{X}$ & $\mathrm{X}^{\mathrm{b}}$ \\
\hline Guatemala & $X$ & \\
\hline Hong Kong & $\mathrm{X}$ & \\
\hline Hungary & $\mathrm{X}$ & $\mathrm{X}^{\mathrm{a}, \mathrm{b}}$ \\
\hline Iceland & & $\mathrm{X}^{\mathrm{a}, \mathrm{b}}$ \\
\hline India & $\mathrm{X}$ & $\mathrm{X}$ \\
\hline Indonesia & $\mathrm{X}$ & \\
\hline Iran & $\mathrm{X}$ & \\
\hline Ireland & $\mathrm{X}$ & $\mathrm{X}^{\mathrm{a}, \mathrm{b}}$ \\
\hline Israel & $\mathrm{X}$ & \\
\hline Italy & $X$ & $\mathrm{X}^{\mathrm{a}, \mathrm{b}}$ \\
\hline Japan & $\mathrm{X}$ & $X$ \\
\hline Kazakhstan & $\mathrm{X}$ & \\
\hline Kuwait & $\mathrm{X}$ & \\
\hline Latvia & & $\mathrm{X}^{\mathrm{b}}$ \\
\hline Lithuania & & $\mathrm{X}$ \\
\hline Malaysia & $X$ & \\
\hline Mexico & $\mathrm{X}$ & $\mathrm{X}$ \\
\hline Moldova & & $\mathrm{X}$ \\
\hline Morocco & $\mathrm{X}$ & \\
\hline Namibia & $\mathrm{X}$ & \\
\hline Netherlands & $\mathrm{X}$ & $\mathrm{X}^{\mathrm{a}, \mathrm{b}}$ \\
\hline New Zealand & $\mathrm{X}$ & \\
\hline Nigeria & $\mathrm{X}$ & $\mathrm{X}$ \\
\hline
\end{tabular}


Table 1. (Continued)

\begin{tabular}{lcc}
\hline Country & GLOBE & $\mathrm{WVS}^{\mathrm{a}, \mathrm{b}}$ \\
\hline Norway & & $\mathrm{X}$ \\
Pakistan & & $\mathrm{X}$ \\
Peru & & $\mathrm{X}$ \\
Philippines & $\mathrm{X}$ & $\mathrm{X}$ \\
Poland & $\mathrm{X}$ & $\mathrm{X}^{\mathrm{b}}$ \\
Portugal & & $\mathrm{X}^{\mathrm{a}, \mathrm{b}}$ \\
Romania & $\mathrm{X}$ & $\mathrm{X}^{\mathrm{a}, \mathrm{b}}$ \\
Russia & $\mathrm{X}$ & $\mathrm{X}^{\mathrm{b}}$ \\
Singapore & & \\
Slovak Republic & $\mathrm{X}$ & $\mathrm{X}^{\mathrm{a}, \mathrm{b}}$ \\
Slovenia & $\mathrm{X}$ & $\mathrm{X}^{\mathrm{b}}$ \\
S. Africa & $\mathrm{X}$ & $\mathrm{X}$ \\
South Korea & $\mathrm{X}$ & $\mathrm{X}$ \\
Spain & $\mathrm{X}$ & $\mathrm{X}^{\mathrm{b}}$ \\
Sweden & $\mathrm{X}$ & $\mathrm{X}^{\mathrm{b}}$ \\
Switzerland & $\mathrm{X}$ & $\mathrm{X}$ \\
Taiwan & $\mathrm{X}$ & $\mathrm{X}$ \\
Thailand & $\mathrm{X}$ & $\mathrm{X}^{\mathrm{b}}$ \\
Turkey & & $\mathrm{X}^{\mathrm{b}}$ \\
Ukraine & $\mathrm{X}$ & $\mathrm{X}^{\mathrm{a}, \mathrm{b}}$ \\
UK & & $\mathrm{X}$ \\
Uruguay & $\mathrm{X}$ & $\mathrm{X}$ \\
USA & $\mathrm{X}$ & $\mathrm{X}$ \\
Venezuela & $\mathrm{X}$ & \\
Zambia & $\mathrm{X}$ & \\
Zimbabwe & &
\end{tabular}

${ }^{\mathrm{a}}$ WVS data from European Values Survey.

${ }^{\mathrm{b}}$ Countries were the decision-making freedom variable was collected in the WVS.

longitudinal research of all measures in the dataset would provide a stronger examination of my hypotheses, such data were not available.

\section{Cultural controls}

While I am interested in the role that organizational leadership and empowerment have on peace, the cultural values of a country (i.e., the shared motives, values, beliefs, identifies, and interpretations of a collectivity (House et al., 2004) may also have an influence peace. One might expect that certain cultural values within a country, like power distance and future orientation, can contribute to peaceful outcomes and thus I control for these influences in the analyses. I discuss each briefly in turn.

Power distance reflects the extent to which a society accepts the fact that power in organizations is distributed unequally (Hofstede, 2003; House et al., 2004). In cultures that value a large power distance, there is a belief that inequalities in society should be recognized and are purposeful. Subordinates are expected to be obedient to leaders. There is a strong reliance on hierarchy and information flows are constrained across levels. As such, cultures with large power distances are embedded with significant latent conflict and hence are more susceptible to corruption and violence.

Future orientation reflects forward-oriented behaviors such as planning, investing in the future, and delaying gratification (Hofstede, 2003). Future-oriented cultures have a vested stake in the long-term outlook for their societies. In governing their citizens, future-oriented countries not only consider the present but ask questions about the future - carefully balancing policies and decisions to benefit both 
living citizens and future generations (House et al., 2004). Future-oriented countries see the building of societies as an iterative game, thereby recognizing that their citizens will need to cooperate across generations and hence are likely to foster more peace.

Culture items are measured on a Likert-type scale ranging from 1 to 7 also from the GLOBE project described above. To assess cultural values, I chose the measures about what society 'should be'. A sample item of power distance is 'I believe that power should be shared throughout the organization, not concentrated at the top'. A sample item of future orientation is 'I believe that people live for the present rather than for the future' (scored inversely). The participative leadership items were also assessed on a 7-point Likert scale and reflect the degree to which managers are not autocratic and involve others in making and implementing decisions. It has a reliability of .85 .

Our intention had been to conduct regression analyses so that the hypotheses could be tested simultaneously. However, given that each of the datasets includes a different subset of countries, when I combine the datasets together for a full test of the hypotheses, we find that our sample size decreases precipitously to 32 countries that are in both GLOBE and the WVS. To have a better sense of the countries in our analyses, I include a list of the countries that are included in the GLOBE survey or the WVS in Table 1. The datasets that measure peace encompass virtually all of these countries included in the datasets measuring the independent variables. Seventy-nine per cent of the countries in our dataset are democracies.

This reduction in countries that are included in the regressions is problematic for two reasons. First, it substantially decreases the power one has to detect relationships. And second, the majority of countries that are common to all of the datasets are democracies. As such, I have limited variance to explain when we focus on this subset of countries. Consequently, while I report the regression findings, we also present a series of correlations to enable the examination of the hypotheses using a larger sample.

\section{Results}

Table 2 provides the correlations and descriptive statistics among all the variables in the hypotheses. I found support for H1 and partial support for H2.

In support of $\mathrm{H} 1$, countries where the leadership of business organizations is more participative are found to be significantly related to less corruption $(r=-.51, p<.001)$ and less unrest $(r=-.57$, $p<.001$ ).

In support of $\mathrm{H} 2$, countries where employees report more freedom to make decisions are found to be significantly related to less corruption $(r=.65, p<.001)$ and less peace $(r=-.61, p<.001)$. In partial

Table 2. Means, standard deviations, and correlations

\begin{tabular}{|c|c|c|c|c|c|c|c|c|c|}
\hline & Mean & $\begin{array}{l}\text { Standard } \\
\text { deviation }\end{array}$ & 1 & 2 & 3 & 4 & 5 & 6 & 7 \\
\hline 1 Future orientation & 2.72 & .33 & 1.00 & & & & & & \\
\hline 2 Power distance & 5.50 & .40 & -.06 & 1.00 & & & & & \\
\hline 3 Participative leadership & 5.33 & .41 & $.32^{* *}$ & $-.42^{* * *}$ & 1.00 & & & & \\
\hline 4 Decision-making freedom & 6.35 & .85 & $.68^{* * *}$ & -.02 & $.69^{* * *}$ & 1.00 & & & \\
\hline 5 Compliance to supervisor & 1.85 & .23 & $-.43^{* *}$ & .18 & -.01 & .04 & 1.00 & & \\
\hline 6 Corruption index & 4.96 & 2.54 & $-.64^{* * *}$ & .02 & $-.51^{* * *}$ & $-.65^{* * *}$ & .12 & 1.00 & \\
\hline 8 Unrest index & 4.53 & 1.20 & $-.50^{* * *}$ & .03 & $-.57^{* * *}$ & $-.61^{* * *}$ & $.32^{*}$ & $.75^{* * *}$ & 1.00 \\
\hline
\end{tabular}


support of $\mathrm{H} 2$, countries where employees reported that there were more compliant in following their supervisor's decisions without question are found to be significantly related to more unrest $(r=.32$, $p<.03)$. However, the relationship between compliance and corruption was not found to be significant $(r=.12, p<.38)$, though it is in the predicted direction.

Interestingly, no significant correlations were found between power distance and corruption $(r=-.02, p<.89)$ or unrest $(r=.03, p<.84)$. But countries that have cultural values that emphasize a high future orientation are found to be significantly related to less corruption $(r=-.64, p<.001)$ and less unrest $(r=-.50, p<.001)$.

Next, I turn to the regression analyses. I use hierarchical regression analyses to show the additional effects that participative leadership and the two empowerment variables add to the effects of cultural values. Again, I am interested in seeing if and how these organizational variables add variance beyond that which would be predicted by each country's cultural values. I add the empowerment variables in a third step after participative leadership because I believe that leadership practices influence empowerment. Given that power distance cultural values were not significantly related to either outcome variable in the correlations, I exclude it from the regression analyses in order to preserve degrees of freedom. Even with the low power due to small sample sizes given different countries' inclusion in different databases, the regression results are significant and generally replicate the correlational results. I first report the corruption findings and then the findings for the unrest outcome (see Table 3).

Regarding corruption, in Step 1, I enter a future orientation culture and find it to be significantly correlated with less corruption $(\beta=-.68, p<.002)$, explaining 46 per cent of the variance. When I add participative leadership in step 2 , it is significantly related to less corruption $(\beta=-.47, p<.025)$ and increases the variance explained to 61 per cent. Finally, I add the two empowerment variables in Step 2. They too are significantly related to corruption (decision-making freedom, $\beta=-.63, p<.003$; compliance, $\beta=-.34, p<.015)$ and increase the variance explained to 83 per cent.

Regarding unrest, in Step 1, I enter a future orientation culture and find it to be significantly correlated with less unrest $(\beta=-.48, p<.04)$, explaining 23 per cent of the variance. When I add participative leadership in Step 2 , it is significantly related to less unrest $(\beta=-.54, p<.04)$ and increases the variance explained to 42 per cent. Finally, I add the two empowerment variables in Step 2. Decision-making freedom is significantly related to less unrest $(\beta=-.77, p<.01)$ while compliance is not found to be related to unrest $(\beta=-.10, p<.33)$. Both variables increase the variance explained to 68 per cent.

These regressions findings provide support for $\mathrm{H} 1$ and partial support for $\mathrm{H} 2$ (decision-making freedom is strongly related to both outcomes while compliance is only related to less corruption).

Table 3. Regression analyses

\begin{tabular}{|c|c|c|c|c|c|c|}
\hline Independent variables & $\begin{array}{c}\text { Step } 1 \\
\text { corruption }\end{array}$ & $\begin{array}{c}\text { Step } 2 \\
\text { corruption }\end{array}$ & $\begin{array}{c}\text { Step } 3 \\
\text { corruption }\end{array}$ & $\begin{array}{l}\text { Step } 1 \\
\text { unrest }\end{array}$ & $\begin{array}{l}\text { Step } 2 \\
\text { unrest }\end{array}$ & $\begin{array}{l}\text { Step } 3 \\
\text { unrest }\end{array}$ \\
\hline Future orientation culture & $-.68^{* *}$ & $-.40^{+}$ & -.16 & $-.48^{*}$ & -.17 & -.11 \\
\hline Participative leadership & & $-.47^{*}$ & $-.32^{*}$ & & $-.54^{*}$ & -.22 \\
\hline Decision-making freedom & & & $-.63^{* *}$ & & & $-.77^{*}$ \\
\hline Compliance to supervisor & & & $.34^{*}$ & & & .10 \\
\hline$F$ & $12.07^{* *}$ & $10.04^{* *}$ & $13.71^{* * *}$ & $3.95^{+}$ & $4.34^{*}$ & $5.28^{*}$ \\
\hline$R^{2}$ & .46 & .61 & .83 & .23 & .42 & .68 \\
\hline$\Delta R^{2}$ & & .15 & .22 & & .19 & .26 \\
\hline
\end{tabular}




\section{Discussion}

This paper began with the question - can business organizations contribute to peace? This initial exploration provides some fledgling support for our hypotheses that participative leadership practices and employee empowerment can foster more peaceable conditions. How? In simple terms, this paper suggests that business organizational leaders can give employees opportunities for voice and empower employees to have more control over their work. From these more participatory work practices, employees will be exposed to some of the key characteristics of peaceful societies. When people get a taste of empowerment at work, they may then seek opportunities for empowerment in civic and political domains. In short, business organizations can develop collective agency so people believe they can intervene in civic and political life as well, leading to more peace.

The idea that business organizations can be a sort of olive branch for peace rather than just a harbinger of excess and exploitation is attractive. Too often, it seems that companies seek to have a positive impact on communities through corporate philanthropy or corporate social responsibility. While these initiatives can be impactful, they are often expensive and can be outside the mission of the firm. This research suggests that business organizations can have a positive influence on peace through their everyday practices around participative leadership and empowerment. While not meant to substitute for more formal philanthropic efforts, this research indicates that business practices affect more than employees and the firms they work for. They can also impact the communities of which they are a part. Business organizations can create models of peaceful societies which can ultimately move societies toward more peaceful outcomes. Even when financial resources are scarce and impede corporate philanthropy, business organizations can still make a positive impact through participative leadership and empowerment practices. Business organizations can do good for peace by creating good business practices. Ultimately, it is a win-win outcome because the business organizations benefit from these progressive management practices while societies benefit from having models for peace.

\section{Complexities inherent in the relationship between business organizations and peace}

But of course the story of how business organizations can contribute to peaceful conditions is more complex. Future research must complicate the model examined here to capture this complexity.

First, labor unions are often intertwined with business organizations and are becoming more global in their reach. At the prodding of unions, employees may engage in strikes to push for political, economic, and social reform. These strikes can turn violent and undermine the economic and social viability of governments. In this way, labor unions are a type of political institution that leverages members to institute change both at the organizational level, in terms of more voice at work, but also at the national level, where they may encourage members to engage in behaviors that may undermine short-term peace (e.g., strikes) with the long-term goal of improving and securing workers rights. So, to the extent that labor unions are part of the equation, the relationship between business organizations and peace may be more complex because they may create unrest in the present with the goal of more peace in the future. Such was the case of Lech Walesa and the Solidarity movement where strikes and unrest preceded the freedom of the country from communism and long-term peace in Poland (Stefoff, 1992). In fact, the UN's Global Compact holds the right to collective bargaining as a central tenet to responsible corporate citizenship and peaceful society (Global Compact, 2006).

Second, while empowerment may be a positive manifestation of voice in business organizations, speaking out in countries with totalitarian leadership may not only work against peace but could also be 
dangerous. There may be times when empowerment can lead to trouble rather than peace. For example, for a woman in Afghanistan, having significant voice might lead to her arrest, or worse. Or, those who speak out against a totalitarian regime may put their livelihood or even their life at risk. Thus, voice in nations with totalitarian regimes may need to be tempered in significant ways.

Third, in some countries peace is forced and not sustainable. Totalitarian regimes may create short-term peace through the repression of conflict. This is not the kind of peace that is sustainablefor it often leads to violent overthrows of the totalitarian government. Our EIU measure of peace does reflect the nature of political and civil rights in a country so this is not a concern with these analyses; however, it is important that any future research in this area focus on peace rather than short-term repression of conflict.

Fourth, it is likely that more peaceful societies may enable more participative practices in business organizations. In other words, the relationship between peace and participation may be bidirectional. Firms may need stable external conditions in order to feel comfortable with more participative practices. In contrast, firms may feel the need to be more authoritarian in a hostile turbulent environment in order to create enough control to operate effectively. Clearly longitudinal research will be necessary for untangling the causality of the relationship.

A final complexity regards the definition of peace. This paper includes two proxies to measure peace - corruption and unrest. But many people, including Nobel Peace Prize Winner Jimmy Carter (2002), would argue that peace is more than the absence of social unrest, violence, or corruption. It is more than stopping war. Future research should conceptualize and examine more positive manifestations of peace, like human and societal flourishing. A more positive conceptualization of peace could be further informed by recent research in Positive Organizational Scholarship (Cameron, Dutton, \& Quinn, 2003).

Future research must also focus on the societal factors that might enable participative leadership and employee empowerment. This paper includes the cultural values of future orientation and power distance. Future work can examine other factors that may influence the prevalence of participation and empowerment including the educational levels of citizens (more education may lead to more empowerment) and the level of homogeneity in social status (more homogeneity may increase empowerment tendencies).

All of these complexities suggest fruitful research agenda areas for advancing our understanding of how business organizations may contribute to peace. My hope is that this exploratory study can be a catalyst for future research.

\section{Strengths and limitations of this study}

This study brings several strengths to the study of peace. First, this paper looks outside the domain of traditional peace research to examine the relationships that organizational leadership and empowerment practices have on peace. And, rather than taking strictly an empirical approach, I begin to develop some theoretical logic for how and why business organizations can contribute to peace that go beyond the more economic and philanthropic rationales that have been offered in prior research. I attempt to show how everyday business practices can foster peaceful conditions. Second, this paper brings together several rich and well-validated cross-national datasets to empirically explore the hypotheses. In this way, I avoid the problem of common methods bias. Third, the datasets are arrayed so that the results are not merely cross-sectional. Instead we look at independent variables measured in the late 1990s/early 2000s and relate them to current outcomes collected in 2004.

Nevertheless, this study has several important limitations. First, though this paper begins to articulate the mechanisms that explain how organizational practices can affect peaceful conditions in civic and 
political domains, it fails to measure any of these mechanisms in our analyses. Thus, I cannot be sure that this logic correctly explains how participative leadership and empowerment practices affect the peace outcomes of interest. Second, because this paper uses secondary data, I have little control over the specific questions that were asked to create our measures. As such, empowerment is measured with two single item measures, so their reliability is questionable. And third, as acknowledged in our analyses section, the sample size for our regression analyses is quite small. Each database collects data on a different set of countries. For example, only 32 countries are in both the GLOBE research and the WVS. So, we have a fairly select set of countries (see Table 1) in our multivariate analyses. The small sample size also limits the power of our analyses. In spite of our low power, however, the results support our hypotheses and are highly significant.

\section{Conclusion}

This exploratory research suggests some new ways for thinking about how business organizations can contribute to peace. In the wake of the turmoil created by September 11, 2001, it is inspiring to think more broadly about how business organizations can be a positive force for change in the world. This research takes one viewpoint on the role of participatory leadership and empowerment. It helps us to begin to consider how even relatively simple practices can have long-term impacts not only on employees and organizations, but also on society and the world.

Let us conclude this paper by quoting peacemaker Elie Wiesel who tells us that 'Peace is our gift to each other'. Perhaps the study of business organizations' contributions to peace may be the gift we as organizational scholars give to ourselves and our world.

\section{Acknowledgements}

I thank Tim Fort and Cindy Schipani for stimulating him to begin to think about this topic through their invitation to the conference on 'Corporate Governance and Sustainable Peace'. I am very appreciative to Andre Delbecq, Jane Dutton, Quy Huy, Denise Rousseau, and Jim Walsh for comments on an earlier draft of this paper. I also thank Eric Neuman, Scott Sonenshein, and Kate Wheeler for their assistance with data collection and initial theoretical ideas.

\section{Author biography}

Gretchen Spreitzer is Professor of Management and Organizations at the Stephen M. Ross School of Business at the University of Michigan, where she also received her Ph.D. Her research has focused on employee empowerment and leadership development, particularly during times of change. At Michigan, she is part of the Center for Positive Organizational Scholarship where her recent research is on enabling employee thriving at work. 


\section{References}

AACSB. (2006). Peace Through Commerce Initiative. http://www.aacsb.edu/members/media/PeaceThroughCommerce22MAR2006.pdf

Allen, V. L., \& Greenberger, D. B. (1980). Destruction and perceived control. In A. Baum, \& J. Singer (Eds.), Advances in environmental psychology (Vol. II). Hillsdale, NJ: Erlbaum.

Anderson, P., Blatt, R., Christianson, M., Grant, A., Marquis, C., Neuman, E., et al. (2005). Understanding the role of mechanisms in organizational research: Reflections from our collective journey. Journal of Management Inquiry, 15, 102-113.

Barber, B. (1995). Jihad vs. McWorld: How globalism and tribalism are reshaping the world. New York: Bellantine books.

Beck-Dudley, C. L., \& Hanks, S. H. (2003). On virtue and peace: Creating a workplace where people can flourish. Vanderbilt Journal Transnational Law, 36, 1637.

Bennett, R. J. (1998). Perceived powerlessness as a cause of deviant employee behavior. In R. Griffin, A. O'Leary-Kelly, \& J. Collins (Eds.), Dysfunctional workplace behavior (pp. 231-238). Stanford, CT: JAI Press.

Bennett, R. J., \& Robinson, S. L. (2000). Development of a measure of workplace deviance. Journal of Applied Psychology, 85, 349-360.

Bobbitt, P. (2002). The shield of Achilles: War, peace and the course of history. New York: Knopf.

Brief, A. P., Buttram, R. T., \& Dukerich, J. M. (2000). Collective corruption in the corporate world: Toward a process model. In M. E. Turner (Ed.), Groups at work: Advances in theory and research. Hillsdale, NJ: Lawrence Erlbaum \& Associates.

Cameron, K., Dutton, J., \& Quinn, R. (2003). Positive organizational scholarship. San Francisco: Jossey-Bass. Carter, J. (2002). The personal beliefs of Jimmy Carter. New York: Three Rivers Press.

Cooperrider, D. (2006). Center for Business as an Agent of World Benefit. Website, ppt://worldbenefit/case.edu/ inquirí

De Jong, G., \& van Witteloostuijn, A. (2004). Successful corporate democracy: Sustainable cooperation of capital and labor in the Dutch Breman Group. Academy of Management Executive, 18, 54-66.

Dutton, J., Ashford, S., O’Neill, R., \& Lawrence, K. (2001). Moves that matter: Issue selling and organizational change. Academy of Management Journal, 4, 716-737.

Fabbro, D. (1978). Peaceful societies: An introduction. Journal of Peace Research, 15, 67-83.

Fort, T. L. (2007). Business, integrity, and peace: Beyond geopolitical and disciplinary boundaries. New York: Cambridge University Press.

Fort, T. L., \& Noone, J. J. (2000). Gifts, bribes, and exchanges in pre-market economies: Lessons for Pax E-Comercia. Cornell International Law Journal, 33, 515.

Fort, T. L., \& Schipani, C. A. (2004). The role of business in fostering peaceful societies. New York: Cambridge.

Fort, T. L., \& Schipani, C. A. (2002). The role of the corporation in fostering sustainable peace. Vanderbilt Journal of Transnational Law, 35, 389-436.

Freeman, R. E. (1984). Strategic management: A stakeholder approach. Boston: Pitman.

Frese, M., \& Day, D. (2001). Personal initiative: An active performance concept for work in the 21 st century. In B. M. Staw, \& R. M. Sutton (Eds.), Research in organizational behavior (Vol. 23). Amsterdam: Elsevier.

Friedman, M. (1970). The social responsibility of business is to increase its profits. New York Times Magazine, Vol. September 13, 1970.

Friedman, T. (2000). The lexus and the olive tree: Understanding globalization. New York: Anchor Publishing.

Friedman, T. (2005). The world is flat: A brief history of the twenty-first century. New York: Farrar, Straus and Giroux.

Global Compact, United Nations. (2006). What is the Global Compact? Website: http://www.unglobalcompact. org/AboutTheGC/index.html

Harrison, J. S., \& Freeman, R. E. (2004). Democracy in and around organizations. Academy of Management Executive, 18, 49-53.

Heidelberg Institute on International Conflict Research. (2006). Conflict Barometer. http://www.hiik.de/en/ index_e.htm

Hirschman, A. O. (1970). Exit, voice and loyalty: Responses to decline in firms, organizations and states. Cambridge, MA: Harvard University Press.

Hofstede, G. (2003). Culture's consequences: Comparing values, behaviors, institutions and organizations across nations. Thousand Oaks, CA: Sage. 
House, R., Hanges, P. J., Javidan, M., Dorfman, P. W., \& Gupta, V. (2004). Culture, leadership and organizations. Thousand Oaks, CA: Sage.

House, R., Javidan, M., Hanges, P., \& Dorfman, P. (2002). Understanding cultures and implicit leadership theories across the globe: An introduction to the project GLOBE. Journal of World Business, 37, 3-10.

Inglehart, R. (1999). Globalization and postmodern values. The Washington Quarterly, 23, 215-228.

Inglehart, R., \& Baker, W. E. (2000). Modernization, cultural change, and the persistence of traditional values. American Sociological Review, 65, 19-51.

Prince of Wales International Business Leaders Forum. (2006). http://www.iblf.org/

Kerr, J. (2004). The limits of organizational democracy. Academy of Management Executive, 18, 81-98.

Korten, D. C. (1996). When corporations rule the world. West Hartford: CoPublications; San Francisco: Berrett-Koehler Publishers [Distributor].

Lawler, E. E. (1996). From the ground up: Six principles for building the new logic corporation. San Francisco: Jossey-Bass.

Milliken, F. J. (2002). How feeling able to speak up at work affects individuals in work and non-work lives. Presentation at the conference on Corporate Governance, Stakeholder Accountability, and Sustainable Peace. University of Michigan Business School, November 22-24.

Nanda, B. R. (1996). Mahatma Gandhi: A biography. Oxford: Oxford University Press.

Nelson, J. (2000). The business of peace: The private sector as a partner in conflict prevention and resolution. The Prince of Wales Business Leaders Forum.

Nichols, P. M. (1999). Regulating transnational bribery in times of globalization and fragmentation. Yale Journal of International Law, 24, 257-263.

Parker, S. K. (2000). From passive to proactive motivation: The importance of flexible role orientations and role breadth self-efficacy. Applied Pscyhology: An International review, 49, 447-469.

Peck, C. (1988). Sustainable peace. The Role of the U.N. and regional organizations in preventing conflict. 9.

Post, J. E., Preston, L. E., \& Sachs, S. (2002). Redefining the corporation: Stakeholder management and organizational wealth. Stanford, CA: Stanford University Press.

Powley, E., Fry, R., Barrett, F., \& Bright, D. (2004). Dialogic democracy meets command and control: Transformation through the appreciative inquiry summit. Academy of Management Executive, 18, 67-80.

Prahalad, C. K. (2004). The fortune at the bottom of the Pyramid: Eradicating poverty through profits. Philadelphia: Wharton School Publishing.

Reuters. (2001). Peru's rainforest natives pin future on ecotourism. Environmental News Network, October 8.

Sachs, J. D. (2005). The end of poverty: Economic possibilities for our time. New York: Penguin Press.

Sen, A. (1999). Development as freedom. New York: Anchor books.

Spreitzer, G. M. (1995). Psychological empowerment in the workplace: Dimensions, measurement, and validation. Academy of Management Journal, 38, 1442-1465.

Spreitzer, G. M. (1996). Social structural characteristics of psychological empowerment. Academy of Management Journal, 39, 483-504.

Spreitzer, G. M., \& Mishra, Aneil. (2000). An empirical examination of a stress-based framework of survivor responses to downsizing. In R. J. Burke, \& C. Cooper (Eds.), The organization in crisis: Downsizing, restructuring, and privatization (pp. 97-118). Oxford, UK: Blackwell Publishers.

Stefoff, R. (1992). Lech Walesa: The road to democracy. New York: Ballentine Books.

Taylor, L., \& Walton, P. (1971). Industrial sabotage: Motives and meanings. In S. Cohen (Ed.), Images of deviance (pp. 219-245). Middlesex, England: Penguin Books.

Unilever. (2005). Brazil: Investing in people. http://www.unilever.com/ourvalues/environmentandsociety/ casestudies/education/brazil.asp

Walsh, J. P. (2005). Book review essay: Taking stock of stakeholder management. Academy of Management Review, 30, 426-452.

Walsh, J. P., Weber, K., \& Margolis, J. (2003). Social issues and management: Our lost cause found. Journal of Management, 29, 859-881.

Weart, S. R. (1998). Never at war: Why democracies will not fight one another. New Haven, CT: Yale University Press.

Weick, K. (1984). Small wins: Redefining the scale of social problems. American Psychologist, 39, 40-49. 